\title{
The Sedimentary Process of Sand Deposits in Bogowonto River, Purworejo, Central Java and Progo River, Kulonprogo, Yogyakarta Using Granulometric Analysis
}

\author{
Proses Sedimentasi Endapan Pasir di Sungai Bogowonto, Purworejo, Jawa \\ Tengah dan Sungai Progo, Kulonprogo, Yogyakarta Menggunakan Analisis \\ Granulometri
}

\author{
Muchamad Ocky Bayu Nugroho, Yody Rizkianto, Riyan Ranggas Yuditama, Akbar Ryan, Agam Maulana \\ Geological Engineering Department, Universitas Pembangunan Nasional "Veteran" Yogyakarta, \\ SWK St. 104 Condongcatur, Sleman, DI Yogyakarta 58283, Indonesia \\ *E-mail: bayu.ocky@gmail.com
}

Article received: 19 August 2021, revised: 11 November 2021, accepted: 16 November 2021

DOI: 10.17146/eksplorium.2021.42.2.6436

\begin{abstract}
Sedimentation is the most traditional separation technique and it is relying on efficient coagulation and flocculation to produce flocs with good settling properties. Bogowonto River and Progo River belong to South Serayu Area. There are similar geological processes that affected the river forming process i.e., erosional process, provenance, and fault systems. The sand sedimentation process for each river could be different due to geometry and river morphology. This research aims to reveal the possible parameters that affected the sedimentary process and sediment material along the stream river. Granulometric analysis was done in this research. Samples were taken from 3 points (upstream, middle, and downstream) of Bogowonto river and Progo river. Statistically, the upstream and middle stream of Bogowonto River shows more dunes and beach environment characters than Progo River. It could be interpreted if Bogowonto has more deposit plain like point bar than Progo River. The downstream area has been interpreted as the upper part of estuarine due to river and beach environment. The volcanic arc (Tertiary \& Quarternary) is the main sediment source for these rivers. The sediment supply of the Progo River is strongly influenced by Merapi's eruption whereas Bogowonto river is dominated by reworked Old Andesite Formation (OAF) \& Sumbing's material. Morphologically, Bogowonto has more meandering features than Progo that indicates the development of river stage in a long time and wide distributed sediment materials.
\end{abstract}

Keywords: Fluvial, Bogowonto, Progo, Granulometric

\begin{abstract}
ABSTRAK
Sedimentasi adalah teknik pemisahan yang paling tradisional dan tergantung pada koagulasi dan flokulasi yang efisien untuk menghasilkan flok dengan sifat pengendapan yang bagus. Sungai Bogowonto dan Sungai Progo termasuk dalam wilayah Serayu Selatan Selatan. Proses pembentukan sungai dipengaruhi oleh proses geologi seperti proses erosi, batuan asal, dan sistem sesar. Proses sedimentasi pasir yang terjadi pada kedua sungai tersebut dapat berbeda berdasarkan faktor geometri dan morfologi sungai. Penelitian ini bertujuan untuk mengetahui berbagai parameter yang mempengaruhi proses sedimentasi dan material sedimen di sepanjang aliran sungai. Metode yang digunakan adalah analisis granulometri pada sampel sedimen yang diperoleh dari 3 titik pada masing-masing sungai (hulu, tengah, dan hilir). Secara statistik, bagian hulu dan tengah Sungai Bogowonto memiliki karakter lingkungan pantai atau bukit pasir yang lebih banyak daripada Sungai Progo. Sungai Bogowonto diinterpretasikan memiliki lebih banyak dataran endapan seperti point bar dibandingkan Sungai Progo. Daerah hilir yang merupakan bagian atas dari muara menunjukkan karakter lingkungan sungai dan pantai yang dominan. Busur vulkanik (Tersier \& Kuarter) merupakan sumber sedimen utama. Pasokan sedimen sungai Progo sangat dipengaruhi oleh erupsi Merapi sedangkan sungai Bogowonto didominasi hasil rombakan OAF \& material
\end{abstract}


Sumbing. Secara morfologi, Kali Bogowonto memiliki ciri lebih berkelok-kelok daripada Kali Progo yang menggambarkan tahap kedewasaan sungai dengan waktu yang lama dan penyebaran material sedimen yang luas.

Kata kunci: Fluvial, Sungai Bogowonto, Sungai Progo, Granulometri

\section{INTRODUCTION}

Separating sediment material is controlled by efficient coagulation and flocculation producing a flocs with good setling properties [1]. Progo river and Bogowonto River are two big rivers in Central Java located in South Serayu Area [2]. The rivers are separated by Kulon Progo High that composed by siliciclastics rocks, carbonate rocks, and volcanic rocks (Figure 1). Those Volcanics rocks are called as Old Andesite Formation. According to Pringgoprawiro and Riyanto [3], OAF is divided into two formations stated as the Kaligesing Formation and the Dukuh Formation. The Kaligesing Formation composed by monomix breccia, with andesite fragments, andesitic lava and sandstone. In the other hand, Dukuh Formation consists of polymix breccia with andesite fragments, sandstone, limestone. That formation was formed during Late Oligocene - Early Miocene. Kulon Progo area is estimated to have deformed at least twice the tectonic phase period during the Tertiary era [4], the first, was occurred during Late Oligocene - Early Miocene, and the second one in the Middle Miocene - Late Miocene that formed as magmatic arcs. The existence of extension faults along of the thrust fault followed by magmatic arc shifting from south to north was indicated as the tectonic development. The magmatic arc from north to south (old to young) named Menoreh, Gadjah and Idjo Mountain.

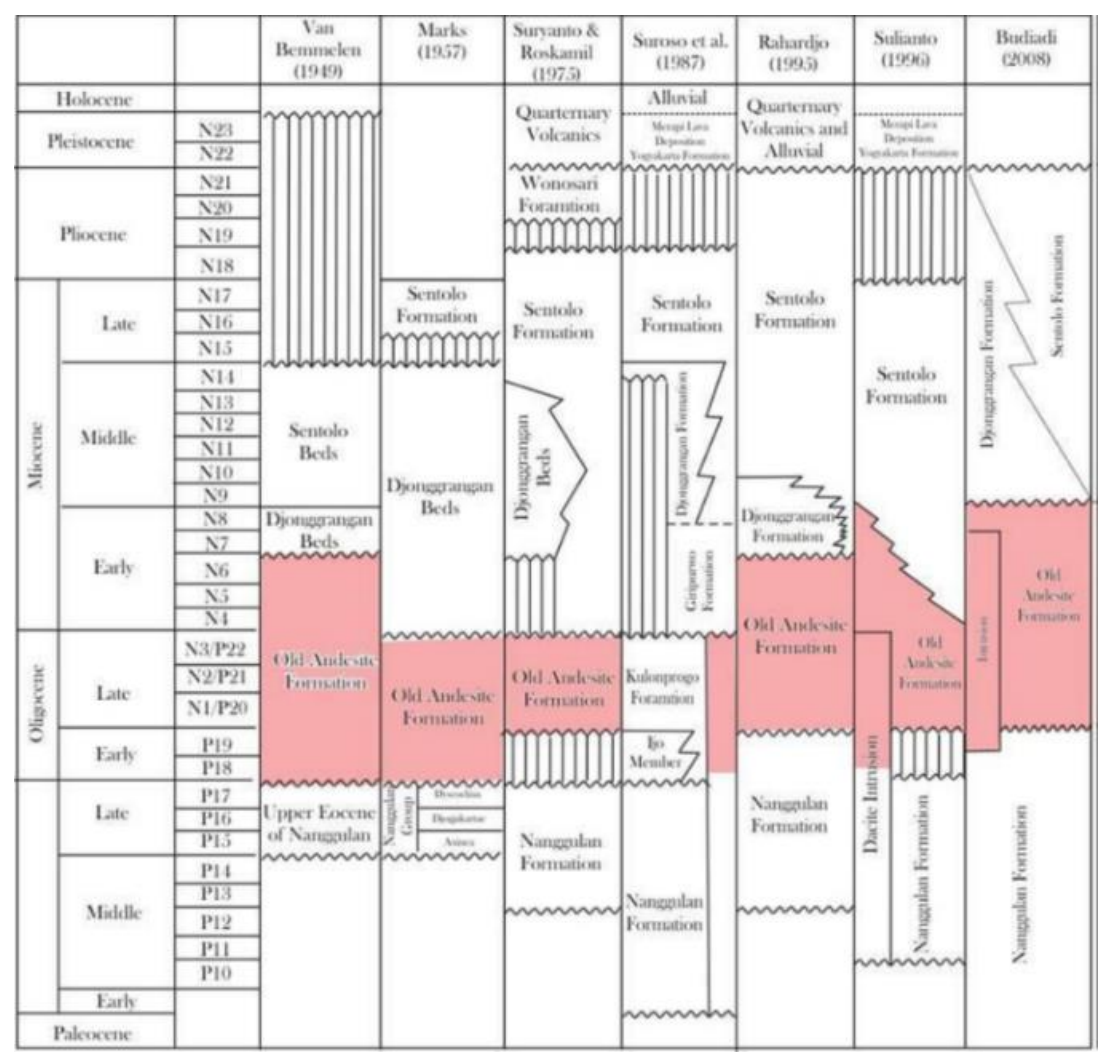

Figure 1. Stratigraphy of Kulon Progo. 
Area along the shore of Central Java are composed of sand deposits derived from volcanic rocks source. There are a lot of rivers with a north-south trend that transport sediment materials. Bogowonto River and Progo River are two rivers in Central Java that have interesting aspects, especially in geological aspect because of the presence of the iron sand. Besides that, the sedimentation process is another point of view that could be interesting too. Generally, the Progo River has massive sedimentation and great geometry compared to the Bogowonto River. Progo River is located in Kulonprogo Regency, Yogyakarta Province, and flows from Mount Merapi to the beach in the south of Java. Bogowonto River existed in the western part of the Progo river about $20 \mathrm{~km}$ of distance.

The granulometric analysis is used to determine the value of quartile, median, diameter, sorting, skewness, and kurtosis by separating the grains from various sizes by the sieving process. Those values are used for references to distinguish the transport mechanism of sediment material and to interpret the depositional environment.

Grain size is a fundamental physical form of sedimentary rock and therefore beneficial descriptive form. Grain size affected several things such as permeability and porosity of the rock that will be very useful for reservoir rock analysis.

This study aims to ascertain the transport mechanism of sediment material and to determine the depositional environment of the Bogowonto River and Progo River using the granulometric analysis.

\section{METHODS}

Methods used in this study are collecting samples and analysis. The analysis phase consists of measurement of sample splitting, mechanical sieving, and plotting data to the graphics. There are 19 samples for granulometric analysis, 10 samples are from Bogowonto River and 9 samples from Progo River.

The samples were collected from three locations for each river, they are upstream, the midstream, and the downstream of the river (Figure 2). Every location is divided into 4-6 sampling points to enrich the variable data. The variation is expected to make the data closer to the real conditions and provide better analysis. Each sample that was picked is fresh and free from impurities such as weathered surfaces and litter. The weight of representative sample is about $1 \mathrm{~kg}$ per sample (Figure 3).

Sample splitting is being done after measuring the weight of the sample thus the data are representative for grain size analysis. The method that used in this study is the quartering method by splitting the samples with board/wood that crossed each other with a funnel. Mechanical sieving has been used to obtain the diameter of sediment size distribution ranging from $2.39 \mathrm{~mm}$ to less than $0.074 \mathrm{~mm}$. After sieving, the samples are measured based on the size of the sieve. Seven sieving used in this research, starting from the biggest sieve is mesh $8(2.39 \mathrm{~mm})$, mesh 16 $(1.19 \mathrm{~mm})$, mesh $30(0.59 \mathrm{~mm})$, mesh 50 (0.297 mm), mesh $100(0.149 \mathrm{~mm})$, mesh 200 $(0.074 \mathrm{~mm})$, and the least sieve is pan $(<0.074$ $\mathrm{mm}$ ) (Figure 4).

The graphics are built based on the result of the measurement after sieving. The graphics present the skewness, kurtosis, sorting of the grain, the percentile of the grain, percentage of the grains transport mechanism, and the depositional environment. The dominat sedimentary process was interpreted based on Steward (1958) Graph. 
The Sedimentary Process of Sand Deposits in Bogowonto River, Purworejo, Central Java, and Progo River, Kulonprogo, Yogyakarta Using Granulometric Analysis Muchamad Ocky Bayu Nugroho, et al.

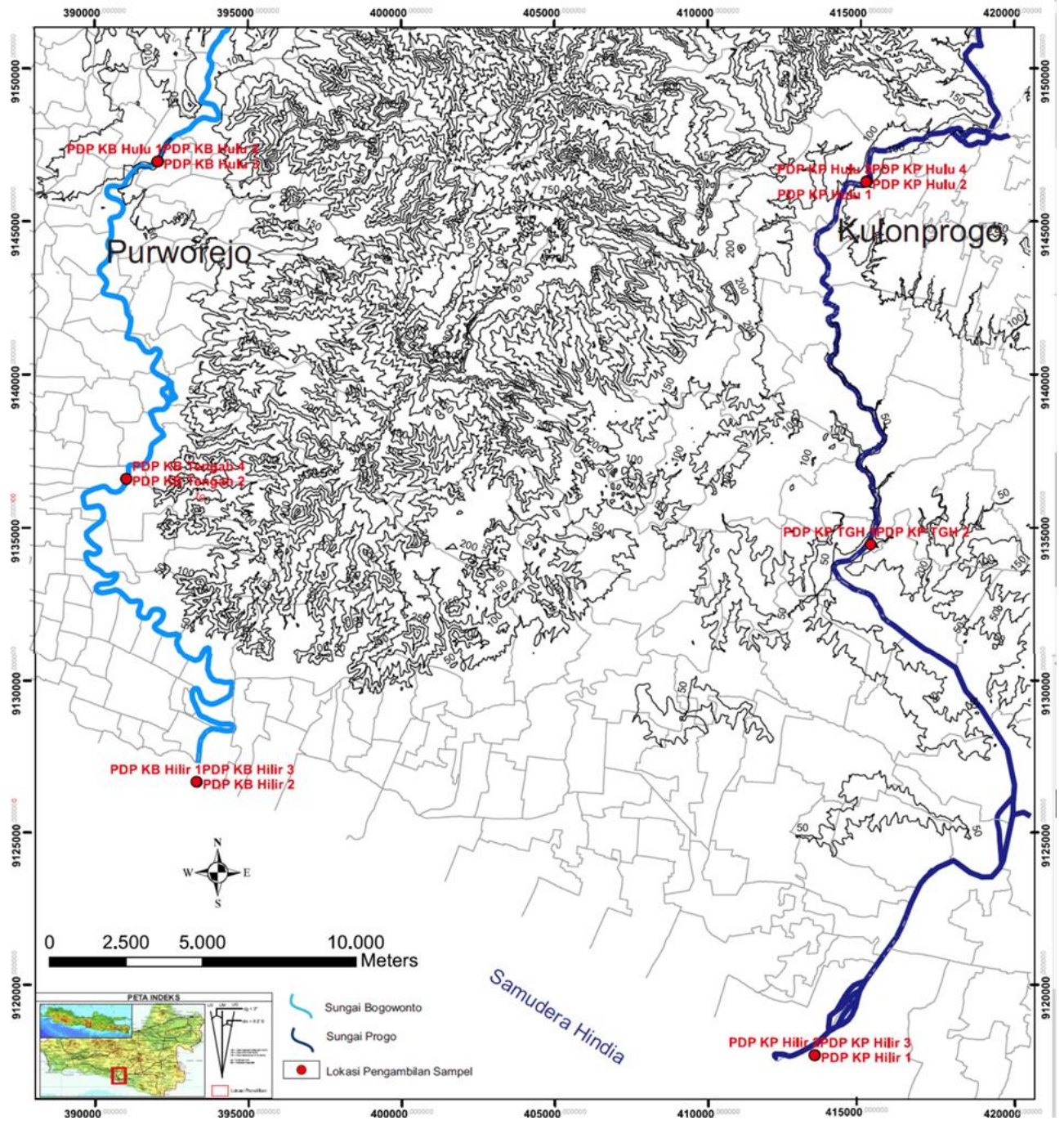

Figure 2. Sampling Location.

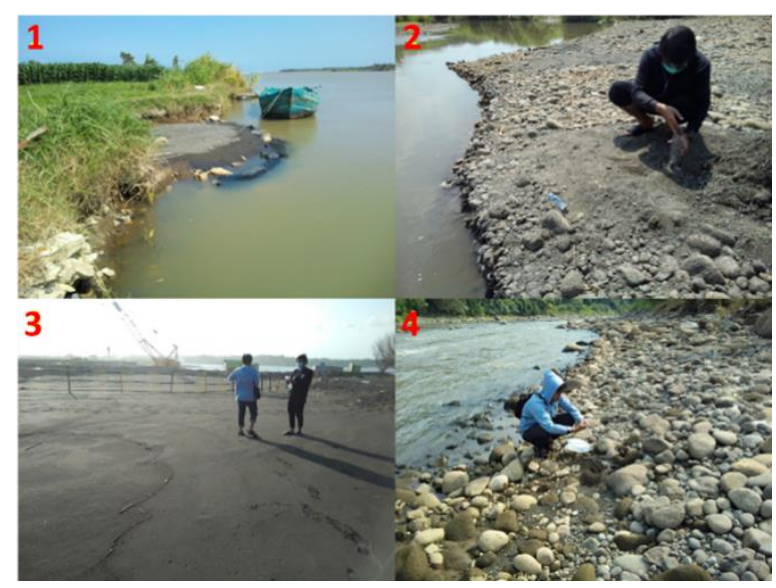

Figure 3. Sampling Location, No 1 (downstream of Progo), No 2 (upstream of Progo), No 3 (downstream of Bogowonto), No 4 (midstream of Bogowonto)

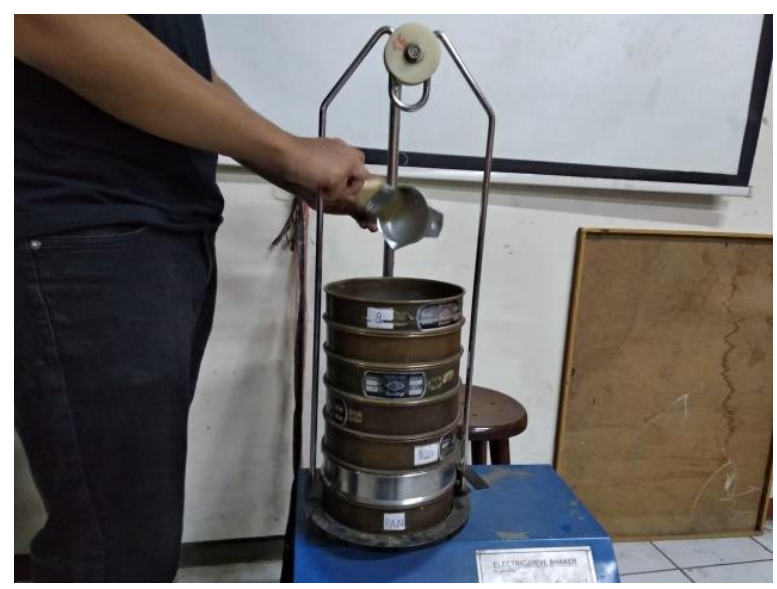

Figure 4. Sieving mesh tools 


\section{RESULT AND DISCUSSION Result}

The characteristics of sand between Progo and Bogowonto river has been summarized by Nugroho et al. [5] based on its grain characters, mineral composition, and river features (Table 1). The granulometric parameter was successfully analysed using five calculation methods, there are: Inman Method [6], Inman Modification method, Folk \& Ward Method [7], Moment Method, and Moment to Mean Method. The results were plotted in several diagrams to interpret the depositional environment and dominant sedimentary process.

Table 1. Characteristics of Progo \& Bogowonto Sand.

\begin{tabular}{|c|c|c|c|c|}
\hline \multirow[t]{2}{*}{ River } & \multicolumn{2}{|c|}{ Grain Character } & \multirow[t]{2}{*}{ Features } & \multirow[t]{2}{*}{ Composition } \\
\hline & Size & Shape & & \\
\hline Bogowonto & Medium - coarse & $\begin{array}{l}\text { Rounded - medium } \\
\text { angular }\end{array}$ & $\begin{array}{l}\text { High sinusoid } \\
\text { meandering channel }\end{array}$ & $\begin{array}{l}\text { Low Feldspar } \\
\text { High Opaque } \\
\text { Low Lithic }\end{array}$ \\
\hline Progo & Coarse - very coarse & $\begin{array}{l}\text { Medium angular - } \\
\text { angular }\end{array}$ & $\begin{array}{l}\text { Low - Medium sinusoid } \\
\text { meandering channel }\end{array}$ & $\begin{array}{l}\text { High Feldspar } \\
\text { Low Opaque } \\
\text { High Lithic }\end{array}$ \\
\hline
\end{tabular}

Upstream data were taken from location near the host rocks. There were 4 point samples from Bogowonto and Progo River. Several diagrams were used to plot the data, there are Friedman (1967) diagram [8,9], Mason \& folk's (1958) diagram, Steward's (1958) diagram [10]. The result was summarized in a graphic to simplify the interpretation. Generally, the upstream area was dominated by river process (Figure 5) and deposited in fluviatile or river environment (Figure 6).

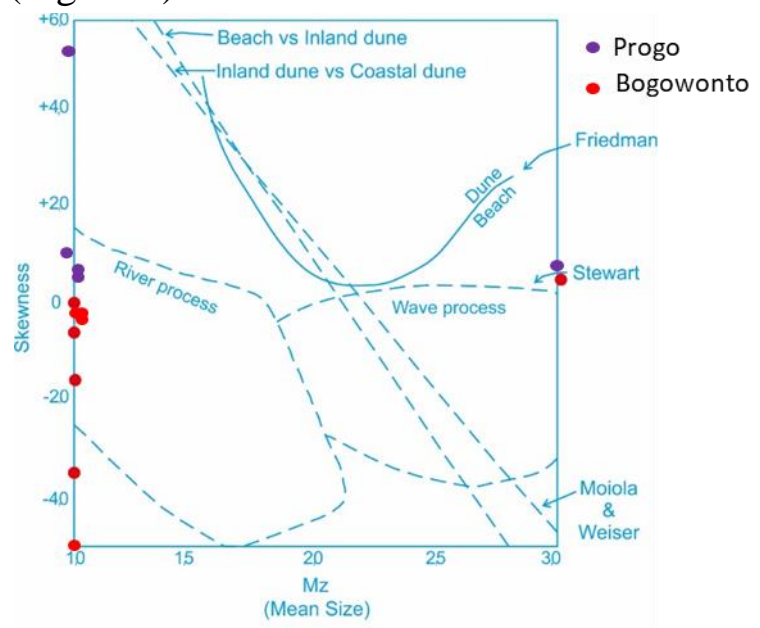

Figure 5. Dominant Sedimentary Process of the upstream based on Steward (1958) Graph.

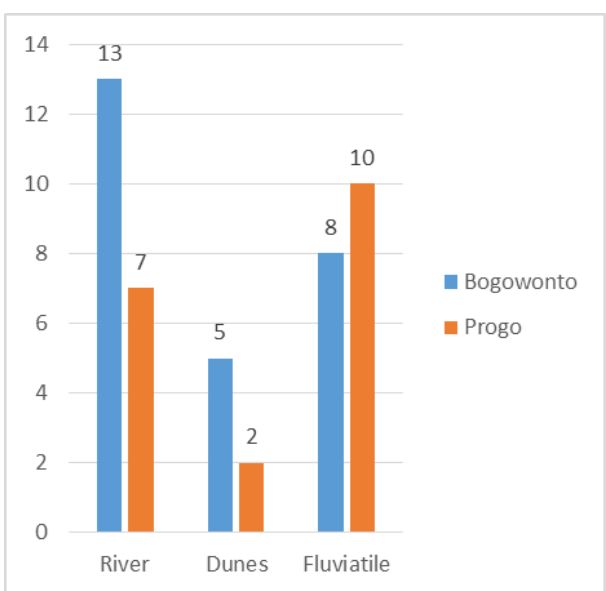

Figure 6. The distribution data of deposition environment from Upstream samples.

The data from the middle area of the rivers shows complex distribution due to the mixture of sediments. The result shows some unrealistic probability of beach environment but quite matched with fluviatile or river environment (Figure 7). The sedimentary process was dominated by the fluviatile or river process although several samples are showing anomalies. Two data shows the wave dominated process and read as minor deviation (Figure 8). 


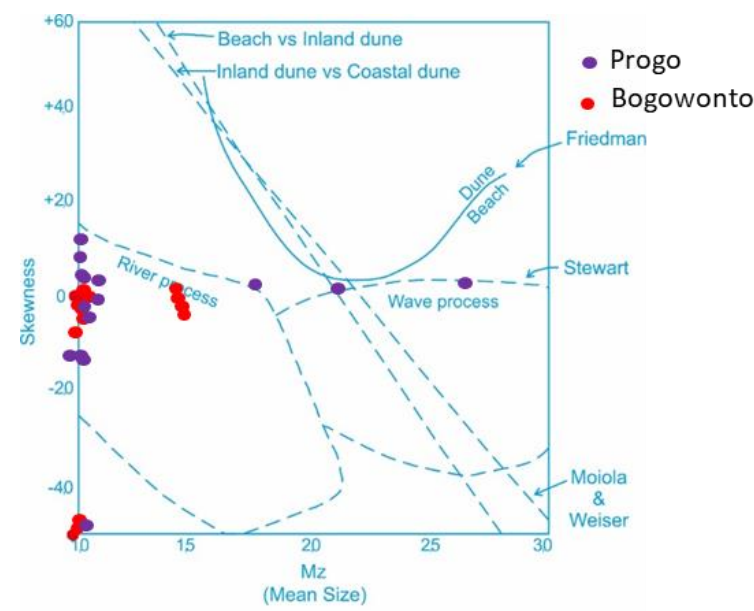

Figure 7. Dominant Sedimentary Process of the middle area based on Steward (1958) Graph.

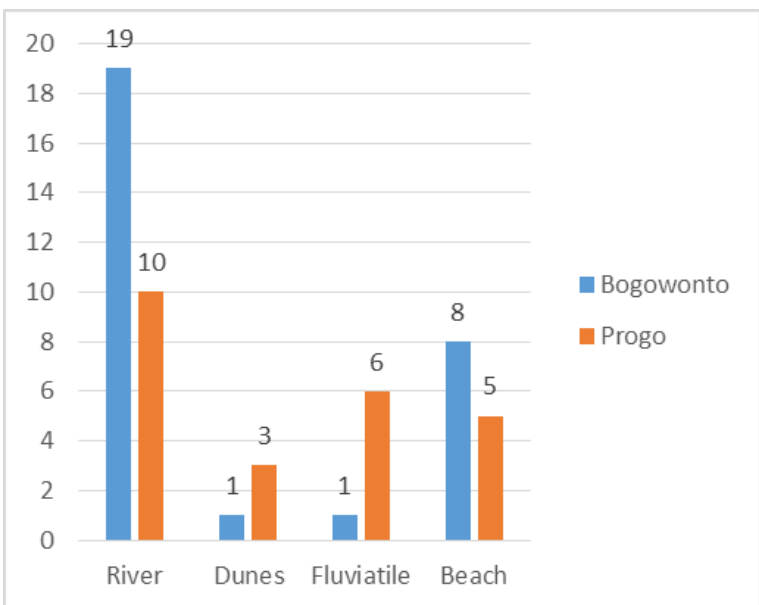

Figure 8. The distribution data of deposition environment from Middlestream samples.

Six samples from downstream were successfully analysed either in Bogowonto and Progo River. According to Steward diagram plotting, the sedimentary process was dominated by fluviatile or river process mechanism (Figure 9). The deposition environment is interpreted as a river to the beach but it could be detailed as the upper zone of the transition zone of beach environment (Figure 10).

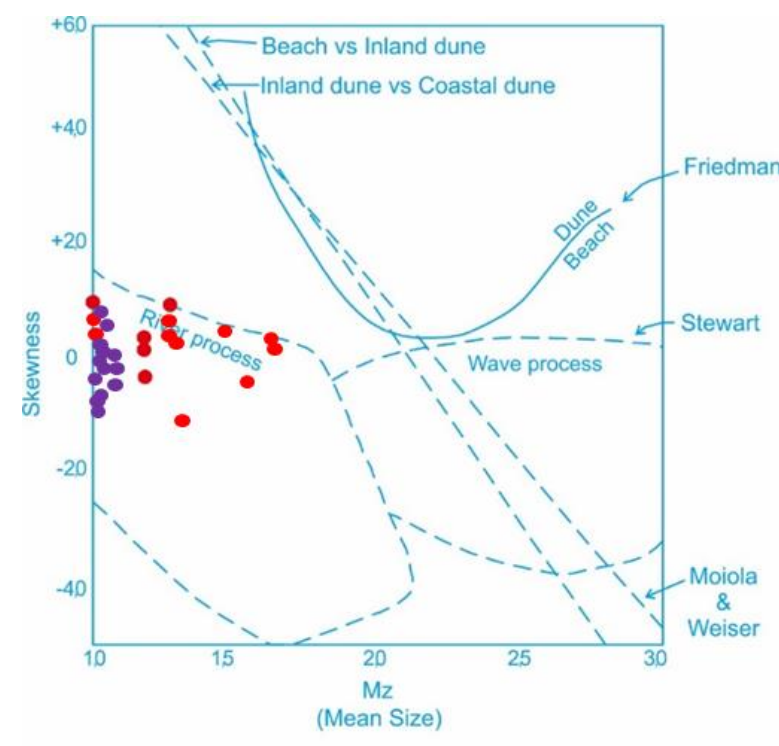

Figure 9. Dominant Sedimentary Process of the downstream based on Steward (1958) Graph.

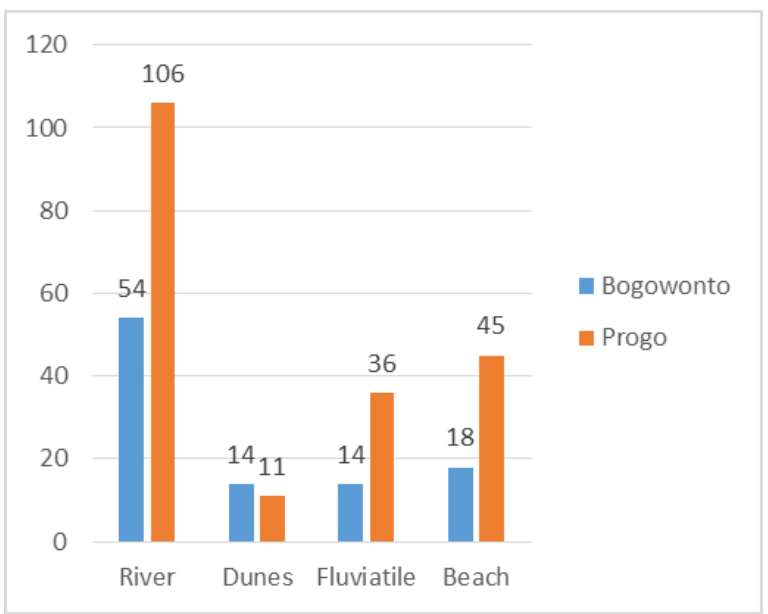

Figure 10. The distribution data of deposition environment from Downstream samples.

\section{Discussion}

Progo River and Bogowonto River are separated by Kulonprogo High which is composed of the Old Andesite Formation (OAF) sequence [11]. Progo river that located in the eastern part of Kulonprogo High was a big and long river body with morphology variation. Bogowonto river is located in the western part of Kulonprogo High and it has relatively low angle terrain with dominant meandering river features indicated as mature stadium [12]. As a periodic river, the external factor like rain discharge that affects the 
sedimentation process is correlated with sedimentary process plotting result (Figure 5, 7, 9). Statistically, the upstream and middle stream for Bogowonto River shows beach or dunes environment character much more than Progo River (Figure $6 \&$ 8). It could be interpreted that Bogowonto river has more deposit plain like point bar than Progo river. The downstream area of both rivers has been interpreted as transition zone such as the upper part of the estuary environment (Figure 10). Both rivers pass through the Old Andesite Formation (OAF) with different distance and mixed material supply (Figure 11).

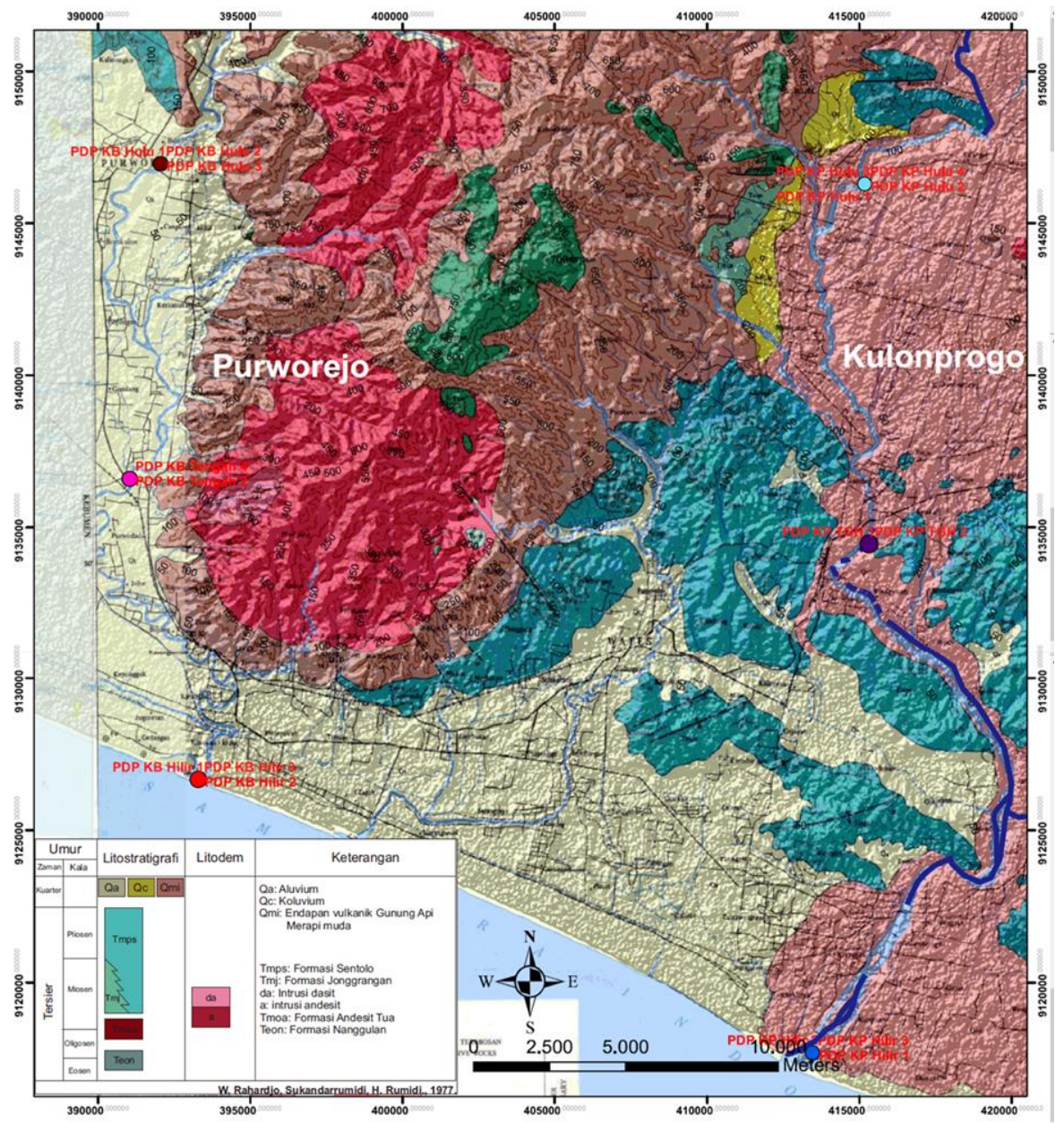

Figure 11. Regional Geological Map Modified [11].

Bogowonto river is located near Kulonprogo High with a lot of creeks tipped on that. This river is one of the oldest rivers in Purworejo plain which deliver the iron sand from OAF to the beach and distributed alongshore [13]. Iron sand deposit is one of the economical minerals in Purworejo that was successfully mined by PT. ANTAM from 1987 to 2007 [13]. The iron sand deposit is a secondary deposit (placer) that comes from the reworked of primary iron ore deposits through hydrothermal processes, metasomatic contact, or sedimentation, in volcanic rocks $[14,15]$. As an ancient river, Bogowonto River has the main role in the distribution of iron sand deposits through the deposition of the KAP (Kipas Alluvial Purworejo) [12]. Iron sand is deposited simultaneously with the deposition of old alluvium and young coastal alluvium found in ancient river flow lanes as charred or riverbanks [16]. 


\section{CONCLUSION}

Both of the rivers have fluviatiledominated sedimentation processes with volcanic provenance. Volcanic material is derived from old volcanism and young (Quarternary) volcanism. The sediment supply of the Progo river is strongly influenced by the Merapi Mountain eruption whereas the Bogowonto river is dominated by reworked existing rocks such as Old Andesite Formation \& Sumbing Mountain volcano-clastics. According to river morphology, Bogowonto has more meandering features than Progo. That morphology shows the maturity of the river stage that has developed for a long time with wide distribution sediment material. It could answer the question "why you cannot find massive iron sand deposits in the eastern part of Kulonprogo High".

\section{ACKNOWLEDGMENT}

The author would like to thank to LPPM UPN Veteran Yogyakarta who funding this research.

\section{REFERENCES}

[1] A. Vlaski, A. N. van Bremeen, and G. J. Alaert, "The Role of Particle Size and Density in Dissolved Air Flotation and Sedimentation". Water Science Technology. Elsevier. Pp 177-189, 1997.

[2] R. W. van Bemmelen, The Geology of Indonesia, Netherlands: Martinus Nyhoff, The Haque, 1949.

[3] H. Pringgoprawiro and B. Riyanto, "Formasi Andesit Tua Suatu Revisi". Prosiding PIT IAGI XVI. Bandung, 1987.

[4] A. Harjanto, "Vulkanostratigrafi di Daerah Kulon Progo dan sekitarnya, Daerah Istimewa Yogyakarta", Jurnal Ilmiah Magister Teknik Geologi, vol. 4, no. 8, p. 30-45, 2008.

[5] M. O. B. Nugroho, Y. Rizkianto, A. Ryan, R. R. Yuditama, and A. Maulana, "The Comparison of
Controlling Factors of Sand Sedimentation Using Mineral Composition and Provenance in Bogowonto River, Purworejo, Central Java and Progo River, Kulonprogo, Yogyakarta". ICEMINE 2021 AIP Proceeding, 2021

[6] D. L. Inman, "Measures for Describing the Size Distribution of Sediments". Journal of Sedimentary Petrology, vol. 30, p. 377-392, 1952.

[7] R. L. Folk, and W. C. Ward, "Brazos River Bar, A Study in The Significance of Grain-Size Parameters". Journal of Sedimentary Petrology, vol. 27, p. 3-26, 1957.

[8] G. M. Friedman and F. E. Sanders, Principles of Sedimentology, USA: Wiley - Library, 1978.

[9] G. M. Friedman, "Distinction Between Dune, Beach and River Sands from Their Textural Characteristics". Journal of Sedimentary Petrology, vol. 31, no. 2, p. 514-529, 1961.

[10] H. B. Stewart Jr, "Sedimentary Reflections On Depositional Environments In San Migue Lagoon, Baja California, Mexico", Bulletin of the American Association of Petroleum Geologists, vol. 42 p. 2567-2618, 1958.

[11] W. Rahardjo, Sukandarrumidi, H. M. D. Rosidi, Peta Geologi Lembar Yogyakarta, Jawa, skala 1:100.000, Direktorat Geologi, Bandung, 1977.

[12] S. Bronto, "Genesis Endapan Aluvium Dataran Purworejo Jawa Tengah; Implikasinya Terhadap Sumber Daya Geologi”, Jurnal Geologi Indonesia, vol. 2, no.4. p. 207-215, 2007.

[13] R. Rahmad, "Identifikasi Permasalahan dan Rekomendasi Strategi Pengelolaan Pesisir Purworejo-Jawa Tengah (Studi Kasus: Areal Bekas Penambangan" PT. ANTAM)". Jurnal Geografi, vol. 8, no.1, p. 15-30, 2016.

[14] A. M. Evans, Ore Geology and Industrial Minerals an Introduction, Blackwell, p. 377, 1993.

[15] B. Tjahjono, B. Pardiarto, N. Sumarna, H. R. Eddy, D. Widhiyatna, and R. Wahyuningsih, Album Geologi Indonesia seri Mineral dan Batuan. Badan Geologi, Bandung, p. 130, 2008.

[16] G. M. L., Junursyah and W. Rahmat, "The Potential of Iron Sand Deposit in the Grabag Area and Its Surrounding Based on Geo-magnet Data". Jurnal Geologi dan Sumberdaya Mineral, vol. 20, no.2. p. 57-83, 2019. 